\title{
Bay Salam: A Proposed Model for Shari'ah Compliant Agriculture Financing
}

\author{
Asim Ehsan ${ }^{1}$, Muhammad Asghar Shahzad ${ }^{2}$
}

\begin{abstract}
This study focuses on the discussion of Salam financing and its prospects in agriculture sector of Pakistan economy. For this purpose, a model of Salam financing is proposed. This model can be used for a single-season crop financing as well as for multiple-seasons crop financing; though the multiple crop finance is relatively complex to execute. Primary objective of the model is the elimination of middleman involvement and specifically addressing problems faced by the small scale farmers. The study also discusses a brief comparative note on the Salam models proposed in the literature and their problems. Risks associated with the proposed model of this study are also mentioned in detail along with their mitigation procedures.
\end{abstract}

Keywords: Bay Salam financing, agriculture financing, farmer, Agriculture Financing.

\section{Introduction}

Islamic economy is based on two main pillars. The first pillar includes the prohibition of Riba (interest), Gharar (uncertainty), and Qimar (gambling) from the financial matters. The second involves the fulfillment of the objectives of Shari'ah. Objectives of Shari'ah are to promote welfare in the society and motivate individuals to help each other. This behavior creates a society welfare system in which poor are helped by rich, so an overall well-off and financially stable society emerges ${ }^{3}$. Islamic finance has gained in this respect a very prominent position and has presented diverse models to provide alternative financing techniques to mainstream interest based economics and financial systems. All these Islamic modes are based on some basic principles, which are totally different from mainstream banking and finance.

Pakistan is an agriculture-based country. The agriculture sector of Pakistan is playing a vital economic role since the independence of country. It contributes $21 \%$

1 PhD Scholar, Islamic Banking $\mathcal{E}$ Finance, International Islamic University, Islamabad asimehsanwahlla@gmail.com

2 Lecturer, Department of Training, Shari'ah Academy, International Islamic University (Faisal Masjid Campus) Islamabad, asghar.shahzad@iiu.edu.pk

3 Siddiqui, N. (2009), "Maqasid e Shariat", Islamic Research Institute, International Islamic University, Islamabad. 
in GDP with $45 \%$ of labor force employed in this sector ${ }^{4}$. More than $65 \%$ of rural population is directly or indirectly connected with agriculture sector (GOP 2007). There is always lack the financial soundness and have to go for loans on interest basis from conventional banks, microfinance banks, NGOs and "arthi" Commission agent. These interest based loans always keep the farmer indebted and farmer never becomes financially well off. Farmers believe that they can save up to $25 \%$ cost of production if they purchase the inputs on cash (Bhutto \& Bazmi, 2007). Interest is strictly prohibited in Islam, According to the Quran:

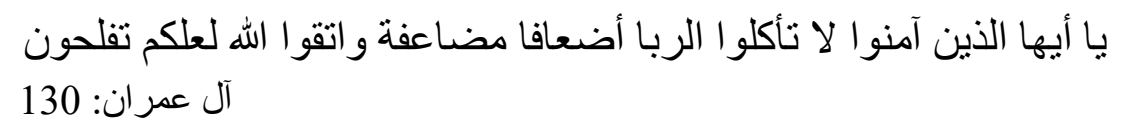

O you who believe! Devour not usury, doubled and multiplied; but fear Allah that you may prosper.

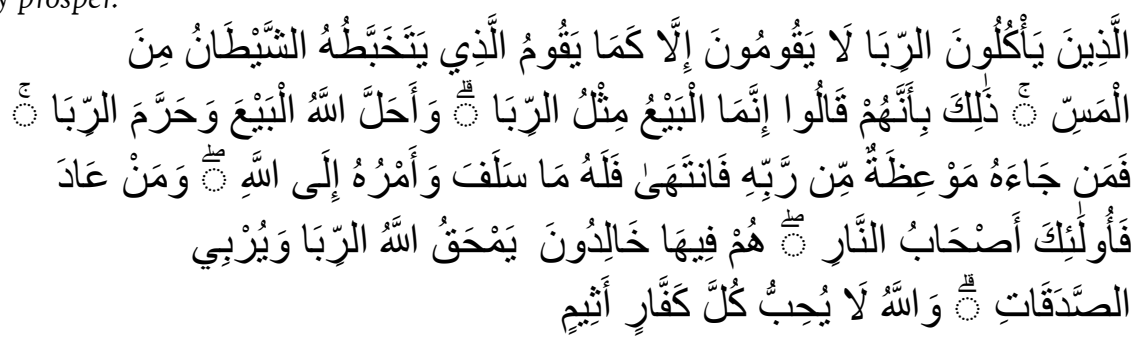

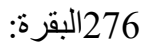

Those who devour Rib (Interest) will not stand except as stands one the Satan has driven to madness by his touch. That is because they have said: "Trade is but like Rib (Interest)." but Allah has permitted trade and forbidden Rib (Interest). So, whosoever after receiving admonition from his Lord desists, he shall be pardoned for the past, and his case is for Allah (to judge); but one who reverts (to the offence), those are the companions of the fire. They will abide therein (for ever). Allah destroys Rib (Interest) and gives increase for deeds of charity, for Allah loves not any ungrateful/non-believing sinner.

The main objective of this study is to introduce an alternative to the conventional (interest based) agriculture financing through Bay Salam, which is novel and different from the other existing Salam models. Existing Salam models, which shall be mentioned thoroughly in later part of the paper. The paper has been divided into two different sections, first section introduces Bay Salam mode of financing in detail, and second section provides an overview of agriculture sector of Pakistan. Existing models of Salam agricultural financing are briefly mentioned in third section. The fourth section of the paper provides explanation of the proposed model of Salam agriculture financing. The fifth section of the paper concludes the study.

4 Pakistan Economic Survey, 2014-15 
The study does not addressed the problem of middleman and in some models they included middleman as a main actor of the model. These models also lack the up gradation of technical skills of farmers. These missing areas are filled in the model proposed by current study. Formation of the paper is as follows:

\section{Bay Salam (Forward Sale)}

The basic principles on which all these Islamic financial modes are based can be understood by defining the sale contract and its features which make it valid. A sale (bay') is a contract which involves at least two parties where two homogeneous or heterogeneous products are exchange against commodity or money. If two homogeneous commodities are exchanged, they should be equal in quantity and exchange should be hand to hand, while in case of exchange of heterogeneous products the quantity can be different, but the condition of hand to hand exchange remains intact. ${ }^{5} \mathrm{On}$ the other hand if the commodity is exchanged with money price will be decided by mutual consent of both contracting parties. According to jurists the contract of sale is permitted from the Quran ${ }^{6}$ with supporting evidences from Sunnah and Ijma.

According to Shari'ah the basic conditions for the validity of a sale contract is the object must be in physical or constructive possession of the seller (Siddiqui, 1977). This condition has three ingredients: first, the object must be in existence, second, the seller should have acquired the ownership of the object and third, mere ownership is not enough, meaning that in addition to ownership, the object must be in possession of the seller, either physically or constructively. If the seller owns an object but he has not taken its delivery himself or via agent, he cannot sell it. ${ }^{7}$

There are two exceptions to the above mentioned general principle of Islamic jurisprudence. The first exception is bay' al-Salam (Salam contract) and the other is Bay Istisna' (advance payment and deferred delivery of the product). Both are sales of a special nature and have acquired the status of an exception to the general principles of sale contract (Zaabi, 2010). Before the prohibition of interest, farmers used to get interest based loans for growing crops and harvesting. After prohibition of interest, they were banned to take interest based loans. Because of this prohibition of interest, farmers and specifically small scale farmers faced liquidity problems. Therefore, in times of the Prophet SAAW, farmers were allowed to take advance price of what

5 Sahih Bukhari: Volume 3, Chapter: Kitab ul Buyuh, Hadith No. 2060, 2061, 2080

6 Al Quran: 2:275

7 There is a general principle that the commodity should be exist and owned by the seller at the time of sale contract otherwise the contract will be void. This principle has been derived from the hadith reported by Hazrat Hakim bin Hizam (R.A.)

$$
\text { حكيم بن حزام رضي الله عنه قال: قلت: يا رسول الله، يأتيني الرجل، فيسألني عن البيع ليس عندي ما أبيعه منه ثم أبتاعه من السوق، النقال }
$$


farmers are going to grow. ${ }^{8}$ This helped them to get money in advance for their needs.

The Arabic word Salam is a noun derived from the verb 'aslam', which means to advance. Therefore, Salam contract is a mode of transaction in which price is paid before delivery of product. The word 'Salf' is also used as a synonym for Salam (Zaabi, 2010).

Salam financing is a Shari'ah compliant transaction, approved from the sayings of the Holy Prophet (SAAW) ${ }^{9}$. It is a special sale contract in which the subject matter does not exist or has not come into existence at the time of payment of the price (Zaabi, 2010). However, since this mode has an important position in everyday dealings, Shari'ah has considered it as an exception to general rule. The testimony to its legitimacy is provided by the Holy Quran and Sunnah, and also from the sayings of companions of Prophet SAAW and Ijma (consensus of the jurists).

Allah Almighty Says in the Holy Quran:

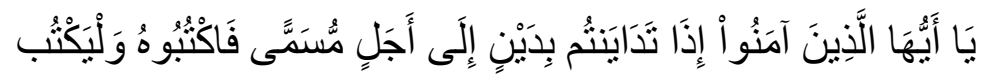

"O Believers! When you contract a debt for a fixed term, you should put it in writing." [2:282]

In Sunnah, the Prophet (SAAW) has forbidden the sale of everything which is not in the possession of vendor, but he made an exception in the case of Salam.

The Prophet (SAAW) said:

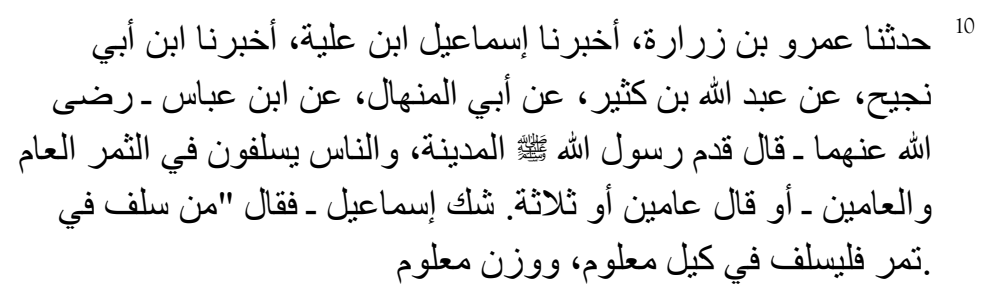

"When a man involves in Salam and pays for goods to be delivered later, the parties should settle the weight and measure and date of delivery of goods."

Abdullah Bin Abi Uffi says that "in times of the Holy Prophet (SAAW) and Abu

8 Prophetic hadith: "when God's Messenger came to Madinah, the people were paying one and two years in advance for fruits, so he said: 'Those who pay in advance for anything must do so for a specified weight and for a definite time.” (Bukhari:2241)

9 Bukhari, Muhammad bin Ismail (194H), Al-Sahih Al-Bukhari, (Berut: Dar Tauq

al-Nijat, 1422H) Kitab al-Salam, Vol, 4, Hadith No. 2240, p.269

10 Bukhari, Muhammad bin Ismail (194H), Al-Sahih Al-Bukhari, (Berut: Dar Tauq

al-Nijat, 1422H) Kitab al-Salam, Chapter: Al-Salam fi Wazn Ma'loom, Hadith No. 2240. 
Bakar (R.A), we used to sell wheat, barley, dried dates, and dried grapes on 'salf'". Salam financing mode is unanimously declared legitimate mode of transaction by all schools of thought, with mere differences in duration issues.

According to all schools of thought, a transaction in which price is paid in advance for the later delivery of goods is Salam (Zaabi, 2010). The person who pays the price in gold, silver, or currency is called Muslim or Rab-ul-Salam. The person who delivers the goods after a fixed period is called "Muslim Alaya". The goods sold are "Muslim Fae" and the price paid is known as "Raas-al -Maal" of Salam. If a man enters into a contract of sale of wheat with another person and makes a prompt payment of price to him upon promise of delivery of wheat later, the transaction would be called Salam.

\subsection{Condition of Bay Salam}

Following are the conditions which should be considered while practicing the Salam financing:

- $\quad$ Price should be paid in advance in full at the time of contract.

- Salam is practiced for only those products which are not scarce in the market.

- Each characteristic of the product should be mentioned at the time of contract $^{11}$.

- Dates, barley, wheat, and grapes were initially allowed in the time of Prophet Muhammad (SAAW). Later, olives and dry grapes were also included ${ }^{12}$.

- $\quad$ Price should preferably be paid in cash but commodities can also be used to pay price. But if Salam product is wheat then wheat cannot be used as price. ${ }^{13}$

- The minimum time duration for the delivery of Salam product is 15 days. ${ }^{14}$

- Guarantee for the delivery of product can be taken from the seller in the form of a written signed paper or in form of any product. ${ }^{15}$

- Contract can be terminated if the seller dies before delivery of the product or if the product before delivery gets destroyed. In both cases, buyer has the right to take back the price paid.

- Seller is not allowed to change the quality, quantity, and point of exchange of

11 Narrated by: Ibne Abbas in Sahih Al Bukhari; Book of Salam, Bab: A Salam contract on a specified weight), 2240, 2241

12 Zuhaili, W. (1997) Fiqh ul Islami wa Adalatuhu, Volume 5, Chapter 1 pp. 3604

13 Ibid

14 Ibid

15 Ibid 
product once the contract is signed and price is paid.

- Both parties in Salam financing can alter or completely cancel the contract by mutual consent.

- Salam product cannot be specified, e.g. wheat of specific part of the land. Doing so invalidates the Salam financing.

\section{Agriculture Sector in Pakistan}

Agriculture sector of Pakistan is playing a vital economic role since the independence of country. It contributes $21 \%$ in GDP with $45 \%$ of labor force employed in this sector ${ }^{16}$. More than $65 \%$ of rural population is directly or indirectly connected with agriculture sector (GOP 2007). Agriculture at the time of independence was contributing 53\% in total GDP of the country with almost all the exports being agricultural products i.e., jute and tea. However, the cliché that Pakistan is an agricultural country is no longer true now, as seen from the current figures of agricultural sector's contribution in the economy (Zaidi 2005). Agriculture has a pivotal role in growth of an economy (Adelman, 2001). It not only provides food and employment for major part of the economy, but also raw materials for most of the industries (Schultz, 1964).

Farm size of Pakistan is about 52,910,408 acres of total 796,096 square km. Average farm size in Pakistan is 6.4 acres with 5.2 acres cultivated (GOP 2010). Average farm size in Pakistan clearly depicts the picture that farmers are not very strong in their financial basis and eventually face problems in this part. They always lack the financial soundness and have to go for loans on interest basis from conventional banks, microfinance banks, and NGOs. These interest based loans always keep the farmer indebted and farmer never becomes financially well off. Interest based loans increase the cost of production. Farmers believe that they can save up to $25 \%$ cost of production if they purchase the inputs on cash (Bhutto \& Bazmi, 2007).

Another option to cope up with the financial problem is the adoption of middleman policy. In this way, farmer is bound to deliver the crop to middleman on a price which is quite low from market price (Mansuri, 1998). Middleman policy to some extent also involves interest at some place and if fuel, fertilizer, or pesticides are taken from middleman, they are charged with inflated prices than market value (Khalid, 2015). All these options lead towards the poverty of producer (farmer) and this poverty increases as every seasons pass (Mansuri, 1998).

It is very necessary to solve the problem and encourage farmers towards agriculture. Farmers are in vicious circle of disappointments and frustrations. They do not have

16 Pakistan Economic Survey, 2014-15 
the liberty to sell their crops on their own (Kaleem, 2008). This problem is very well addressed by adopting Salam financing mode specifically to assist small scale farmers financially and all other farmers in general.

Table 1: Supply of Agricultural Credit by Institutions

\begin{tabular}{|c|c|c|c|c|c|c|c|c|}
\hline \multirow{3}{*}{$\begin{array}{l}\text { Table: } \\
\text { Banks }\end{array}$} & \multicolumn{5}{|c|}{$\begin{array}{l}\text { Supply of Agricultural Credit by Financial Institu- } \\
\text { tions }\end{array}$} & \multirow{2}{*}{\multicolumn{3}{|c|}{$\begin{array}{c}\text { Rs. In Billions } \\
\text { 2014-15 (July - March) }\end{array}$}} \\
\hline & \multirow{2}{*}{$\begin{array}{c}\text { Target } \\
2013-14\end{array}$} & \multicolumn{3}{|c|}{ 2013-14 (July - March) } & \multirow{2}{*}{$\begin{array}{c}\text { Target } \\
2014-15\end{array}$} & & & \\
\hline & & Flow & $\begin{array}{c}\% \text { age } \\
\text { Achieved }\end{array}$ & $\begin{array}{l}\text { \% Share } \\
\text { in Total }\end{array}$ & & Flow & $\begin{array}{c}\% \text { age } \\
\text { Achieved }\end{array}$ & $\begin{array}{l}\text { \% Share } \\
\text { in Total }\end{array}$ \\
\hline $\begin{array}{c}5 \text { Major } \\
\text { Banks }\end{array}$ & 188.0 & 133.5 & 71.0 & 52.2 & 252.5 & 167.4 & 66.3 & 51.3 \\
\hline ZTBL & 69.5 & 45.9 & 66.0 & 17.19 & 56.2 & 56.2 & 62.4 & 17.2 \\
\hline $\begin{array}{l}\text { DPBs } \\
(15)\end{array}$ & 90.4 & 54.2 & 60.0 & 21.2 & 72.1 & 72.1 & 62.4 & 22.1 \\
\hline PPCBL & 10.0 & 5.4 & 54.5 & 2.1 & 5.9 & 5.9 & 50.9 & 1.8 \\
\hline $\begin{array}{c}\text { MFBs } \\
(7)\end{array}$ & 21.6 & 16.2 & 75.1 & 6.3 & 20.7 & 20.7 & 73.6 & 6.3 \\
\hline $\begin{array}{l}\text { Islamic } \\
\text { Banks } \\
(4) \\
\end{array}$ & 0.5 & 0.5 & 94.6 & 0.2 & 3.7 & 3.7 & 162.2 & 1.1 \\
\hline Total & 380.0 & 255.7 & 67.3 & 100 & 326.0 & 326.0 & 65.2 & 100.0 \\
\hline
\end{tabular}

Sources: Economic Survey of Pakistan 2014-15

Above mentioned table explains the distribution of agriculture credit by commercial banks, Zarai Taraqiati Bank Limited (ZTBL), and other financial institutions. In 2013-14, Rs. 380 billion was the target to issue the credit to farmers, while in 2014-15 it grew to 252.5 billion rupees ${ }^{17}$. This picture states the requirement of financial aid by the farmers of Pakistan. Farmers go for these credit schemes as they do not have any other choice to realize the financing needs. This point outs the necessity of a substitute model which augments the farmers' financial and technical skills and it can only be accomplished if the farmer gets full liberty in allocation of finances and sale of crops. This study proposes a model which suggests Islamic banks, microfinance institutes, and NGOs to adopt a way in which benefit by both parties, i.e. financier and farmer, is shared equally. This phenomenon will surge the growth of agricultural sector of Pakistan and subsequently boost the GDP.

Salam model is based on the principle of helping small scale and medium size farmers specifically and exterminates the role of middleman's financial callousness.

17 Pakistan Economic Survey, 2014-15 
Before explaining the proposed model, it is necessary to briefly mention the existing models of Salam financing in agriculture sector and their respective pros and cons.

\section{Theoretical Analysis of Existing Models}

This part of the paper theoretically analyzes the existing models of Salam mode of financing regarding agriculture. It has been observed that none of the Islamic banks of Pakistan are involved in Salam financing except one. In this chapter the proposed models mentioned in previous research papers are evaluated. Rasheed and Mudassar (2010) proposed a model involving middleman as agent of bank (financier). Middleman, as agent of the bank sells the crop in market and charges his agency fee. Same sort of model is proposed by Wajid and Kaleem (2009). These models are correct in their formation but they violate the true spirit of Salam financing. The true spirit of Salam financing is to provide maximum possible financial benefit to the farmer. One way to provide this benefit is by reducing the number of hands involved in bringing the crop from fields to market. Lesser the number of hands in this process, higher will be the financial benefit to farmers. Above mentioned models are still keeping the role of middleman who is the main exploiter of farmer. Middleman as agent in the model increases the overall cost of model because the bank or any other financier buys the crop from farmer with lesser price than in situations where no middleman is involved.

Some other models propose the parallel Salam technique for the financier in order to sell the crop. This reduces the number of hands in selling the crop but it is sacrilegious to the purpose of allowing Salam financing. Salam is an exception of sale contract and it is allowed by the Prophet SAAW specifically for farmers. The main objective of allowing this exception to the sale contract by Prophet SAAW was to provide an alternative to interest based loans, which farmers used to take for growing their crops. ${ }^{18}$ Banks or financiers do not face the problem of any kind of finances; therefore, parallel Salam does not fulfill the true purpose of Salam. Shari'ah has provisioned the exceptions for special purposes and as soon the special purpose vanishes, the exception also no longer exists. For example, the exception given on eating pork meat is, when a person is dying of hunger and finds nothing else to eat. When he eats few grams of pork which liberates him from the fear of dying, the exception also dies. Similarly, the exception of Salam financing is provided to small scale farmers in order to fulfill their financial needs after the prohibition of interest. Salam financing would be no longer be applicable to the entities which are not in need of financial aid. Current study is focused on provision of a Salam model for agriculture financing which does not include parallel Salam.

18 Bukhari, Muhammad bin Ismail (194H), Al-Sahih Al-Bukhari, (Berut: Dar Tauq al-Nijat, 1422H) Kitab al-Salam, Vol, 4, Hadith No. 2240, p.269 


\subsection{The Salam Agriculture Model}

Salam model is an encouragement for those farmers who sometimes stay away from banks and other financial institutions because of the element of interest. It is necessary to design a model which not only addresses the problems mentioned in the previous models but also propose alternatives for issues mentioned in the previous section. The model proposed in this research study is an attempt to achieve the above mentioned objectives.

1. In this model there are two parties, one is farmer, or seller of the product and the other is financier/ buyer of the product. Farmer and financier both enter into a contract of Salam for the agricultural product i.e. wheat. The farmer owns 10 acres of land and requires financing for that land in order to sow wheat. Financing will be provided for the period of one crop, which is estimated to be $5-6$ months.

2. Financier, which is a company, bank, or any other institute, hires an inspection team (specifically agricultural specialists) who will inspect that 10 acres land and estimate its production capacity. On the basis of the report provided by agriculture specialists, the quantity of wheat will be decided in order to mention it in the Salam contract. This estimate of production capacity can also be seen from the average production per acre land of that area and it shall reduce the cost of hiring agriculture specialists.

3. Once the quantity of wheat is decided, the price of the wheat which is to be paid in lump sum at the time of contract is set. For evaluation of price, economic experts can be hired to forecast the price of wheat after 5 months when the wheat is actually available. In order to forecast the price of future wheat a trend can be set up via analyzing the previous 5 to 10 years' wheat prices. This provides a very clear picture for anticipating the future price. It is normally proposed in Salam financing literature to discount the market prevailing price and pay that discounted price to farmer so that the financier is able to earn profit at the time of crop delivery (Farrukh, 2011). Forecasting the price through past 5 to 10 years' prices will help the financier as well as the farmer to set mutually agreed and beneficial price. This is a simple technique which does not necessarily require any economic specialist to forecast the future price. Therefore, a specific amount of price is set and paid at the time of contract.

At the time of signing Salam financing contract, quality of the product should also be mentioned along with the quantity. Decided quality mentioned in the contract cannot be changed by the farmer at the time of delivery of the product. But mere differences can be ignored by the financier in case of quality parameters. Date of delivery shall be decided at the time of contract and farmer is obliged to deliver 
the product at the due date. Guarantee can also be taken into consideration so that the product is delivered in time and of same quality. However, in order to ensure the quality of product and its timely delivery, the financier or donor should send any of its employees, preferably agriculture specialist, to inspect the crop on monthly or bi-monthly basis. This helps donor to be satisfied with the performance of farmer and also ensures the crop delivered at the time of contract completion is same which financier's inspectors are inspecting. Such inspection should also include proper and effective suggestions to farmers in order to increase the efficiency of their work. This in turn will help the farmers to get acquainted with the modern technologies and parameters of agricultural activities and procedures.

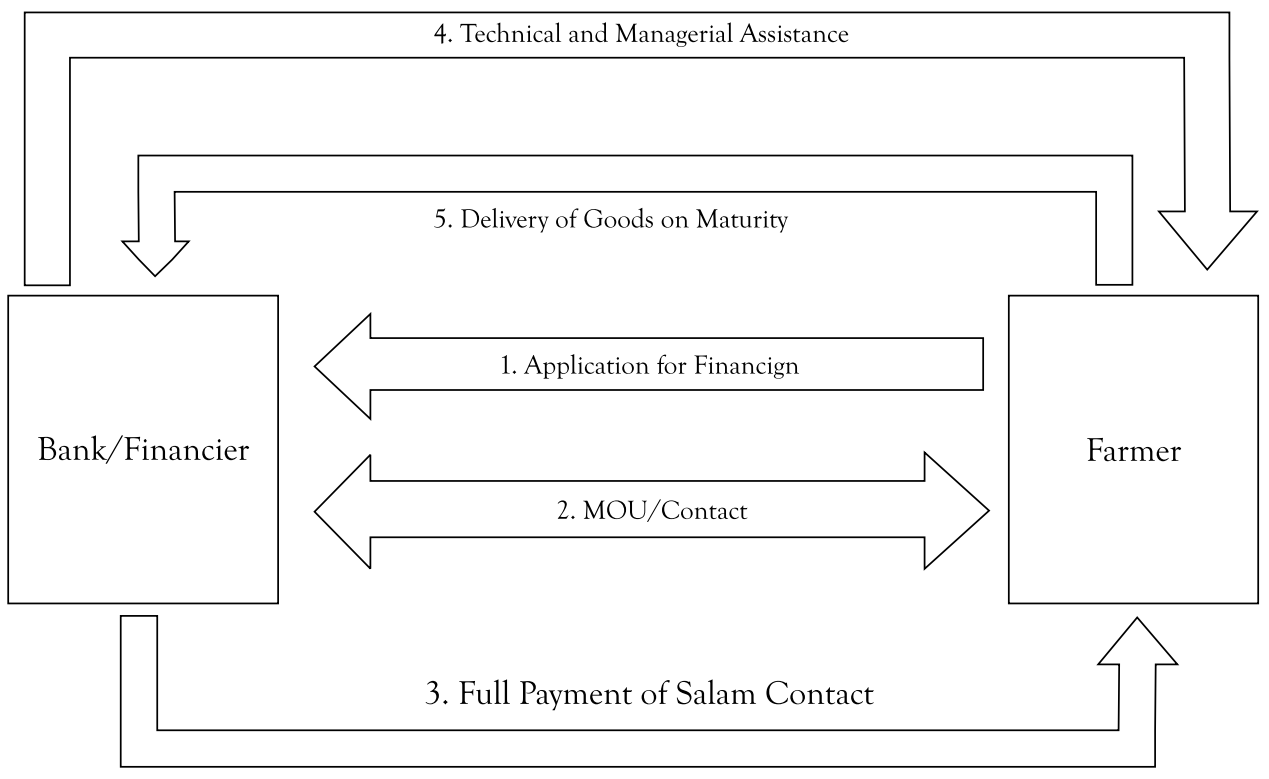

Process Flow of Proposed Salam Contract: (Figure 1)

At the time of contract completion, the financier can either hire an agent to receive the product from the farmer (which is allowed as mentioned above in the conditions of Salam) or it can be the farmer himself to sell the product directly to the financier. But the financier cannot sell that product if it has not yet come under his possession. It is allowed in Shari'ah, that buyer or farmer (with new contract not contingent on the Salam contract) can act as agent of seller and take possession of the product which he is supposed to buy/deliver on behalf of financier. Once the wheat comes under constructive possession of the financier, he can sell it to flour mills or crop markets.

Other possibility can be that the flour mill only takes possession of wheat, grinds it into flour and charges its service fee. Flour remains in the possession of financier 
and he can sell it to someone else or arrange his own distribution centers or outlets to sell. This situation helps the financier to earn more profit. Another possibility is that financier holds the wheat for some time and then sells it in market but with the condition that the wheat in times of storage does not get scarce in the market.

Below mentioned table (Table 2) which is showing price of wheat (40 kg) for the last 7 years. These prices correspond to times when the wheat is reaped. This table will be used to set a trend in prices and to forecast the future price as well. For instance, to forecast the wheat price for 2015, a figure can be taken which would almost be same as actual if the respective conditions are met. Other factors which can affect the price are demand levels in times of forecasting the price and government's behavior towards wheat production which also plays a significant role. If conditions remain the same as they are now, then the price 1250 rupees per $40 \mathrm{~kg}$ can be selected (the forecasted wheat price of 2015). This forecasting is for financier and after evaluating the future expected price; he can come up with a price around the forecasted price by mutual agreement between him and the farmer.

Table 2: Prices of wheat for the last 7 years

\begin{tabular}{|c|c|}
\hline Year & Price per $40 \mathrm{~kg}$ (Rs.) \\
\hline 2014 & 1250 \\
\hline 2013 & 1200 \\
\hline 2012 & 1050 \\
\hline 2011 & 1050 \\
\hline 2010 & 1030 \\
\hline 2009 & 900 \\
\hline 2008 & 900 \\
\hline
\end{tabular}

Source: Pakistan Agriculture Research and Pakistan Bureau of Statistics ${ }^{19}$

Justification of choosing the above mentioned technique for price forecasting is that the best forecast of tomorrow's prices is today's prices. Another reason is historical information embedded in a commodity price is used for forecasting. Forecasting the future price by consulting past prices is the most efficient and easiest way (Bowman and Husain, 2004). This process does not require a lot of details regarding the commodity and other particulars of the commodity but just a price. So this process is extracting near to perfection results through minimum but effective information.

Evaluation of price will also include the operating costs, material costs, and transportation costs. After considering all these and other related costs, price of the 
crop in coming season will be determined which becomes part of the Salam contract between farmer and the financier.

\subsubsection{Risk Management of the Model}

It is necessary to know the risks involved in this proposed model and how to mitigate them. Following are the risks involved in the above mentioned Salam agriculture financing model.

Delivery/Default Risk: This risk is prominent in the model because of the delayed delivery of the product. There is a possibility that the farmer could default in delivering the product, even though the crop may not have been destroyed by any catastrophic event. This risk can be mitigated by taking some mortgage security or gold etc. as guarantee. ${ }^{20}$

Commodity Risk: This risk involves the possibility of non-delivery of the crop due to any catastrophic damage to that crop, e.g., floods, draught etc. This risk can be mitigated through indulging in Takaful service for the crop. Takaful would compensate the farmer financially in case of any damage to the crop.

Price Risk: Financier faces the risk of uncertain price movements of the product during the 6 months period contract whose price is already paid. There is a great uncertainty that the price of crop to be financed through Salam declines.

Quality Risk: This risk can occur if the quality of the crop decided in the contract of Salam is not exactly the same which is to be delivered by the farmer. In this case financier faces quality risk. This problem can be dealt through frequent visits to farms by agricultural experts assigned by the financier, whose job would be to ensure the crop health.

\subsection{Prospects of this Model}

This model is diverse in the sense that not only it provides easy and swift finance to farmers, but also counsels them in order to excel their expertise and make them more compatible with current agricultural developments. This model will empower farmers with skills and finances, and make them free from the middleman's financial slavery. All the services provided by financier will be free and nothing extra would be taken other than the crop from the farmer.

There shall be no middleman in this model which is because of the following reasons:

20 Zuhaili, W. (1997) Fiqh ul Islami wa Adalatuhu, Volume 5, Chapter 1 pp. 3604 
- It is not financially beneficial for financier to include middleman. It decreases financier's profit margin.

- Economic objectives of the Salam financing cannot be achieved by including middleman.

- Including middleman in Salam model would put the model into ambiguities in respect of Shari'ah rulings on Salam financing.

This model is more suitable for financiers or group of financiers which are related to the agricultural sector. For example, the Salam financing for wheat crop can be financed by flour mills or other related entities. This way the technique of Salam model remains simple, clean, and more compatible with the Shari'ah rulings.

\section{Conclusion}

This study proposes a model designed for the agricultural sector in which farmers and specifically small scale farmers are supposed to be the main beneficiaries. The model is based on Salam financing technique. In it, the role of middleman is reduced to zero and the financier or buyer (fund provider) acts as middleman. As a result, this model reduces the hands involved in trading of agricultural products from the farmers.

Salam financing and its Shari'ah legitimacy is also thoroughly discussed in this article but main focus of the study is the proposition of a model, which is based on Salam financing. The main emphasis of the model is that the small scale and also large scale farmers can avail the finances for their crops in advance and have the liberty of selling crops on prices which they desire. Middleman normally exploits the farmers in respect of price of the crop and prices of the inputs and these issues are obviously tackled in this model.

This model is novel because not only it shows concerns about the financial stability of the farmer but also focuses on enhancement of technical skills of the farmer. This would empower farmers financially and technically and eventually the productivity of the field will increase. This model will also provide new dimensions to traders and financiers by devising a Shari'ah compliant model which is being practiced from the times of Prophet SAAW and is approved by him.

\section{References}

Sidiqqui, N. (1977). Islam ka Nazriya-e-Malkiyat. Lahore, Pakistan: Islamic Publications.

Usmani, M. T. (2005). An introduction to islamic finance. Karachi, Pakistan: Maktaba Ma'arif ul Quran.

Siddiqui, N. (2009). Maqasid e Shariat. Islamic Research Institute. International Islamic University, Islamabad. 
Bhutto, W. A., \& Bazmi, A. A. (2007). Sustainable agriculture and eradication of rural poverty in Pakistan. UK: Blackwell Publishing.

Agriculture Census 2010, Pakistan Report. Statistics Division, Government of Pakistan.

Salam Based Financing for the Farm/Crop production purposes. Islamic Banking Department, SBP. "Handbook on Islamic SME Financing" Islamic Banking Department, SBP.

Zaabi, S. O. (2010). Salam contract in islamic law: A survey. Review of Islamic Economics, 14(2), 91-122.

Farrukh, Z. (2011). The analysis of application of salam and istisna'a in islamic financial industry. Journal of Islamic Banking E⿱ Finance, Oct-Dec, 2011, 18-22.

Adelman, I. (2001). Beyond export led growth. World Development, 12(9), 937-949.

Schultz, T. W. (1964). Transforming traditional agriculture. New Haven: Yale University Press.

Mansuri G. (1998). Credit layering in rural financial markets. PhD Dissertation. Boston University.

Kaleem, A. (2008). Application of islamic banking instrument (Bay Salam) for agriculture financing in Pakistan. Islamic Finance for Micro and Medium Enterprises by IRTI, IDB.

Wajid and Kaleem (2009). Application of islamic banking instrument (Bay Salam) for agriculture financing in Pakistan. British Food Journal, 111(3), 275-292.

Zaidi, A (2005), Issues in Pakistan Economy. Karachi: Oxford University Press.

Khalid, A. (2015). Promoting Agriculture Financing through Islamic Banks Challenges $\mathcal{E}$ Opportunities. International Conference on Innovative Agricultural Financing, 28 $8^{\text {th }}-29^{\text {th }}$ April, 2015.

Rasheed \& Mudassar (2010). Research on innovative models of islamic banking product for Pakistani farmers. Proceedings of the $7^{\text {th }}$ International conference on Innovation \& Management

Bowman and Husain (2004). Forecasting commodity prices: Futures versus judgment. IMF working paper, WP/04/41, International Monetary Fund.

Zuhaili, W. (1997). Fiqh ul Islami wa Adalatuhu, Volume 5, Chapter 1 pp. 3604. 